\title{
Badania zużycia frettingowego w połączeniu obrotowym koło-oś zestawu kołowego z automatyczną zmianą rozstawu kół
}

\begin{abstract}
W artykule przedstawiono problem zużycia wystęujacy w potaczeniu obrotowym koło - oś zestawu kołowego z automatyczna zmiana rozstawu kót. Zwrócono uwage na różnice rozwoju zużycia frettingowego $w$ tradycyjnym zestawie kołowym a w zestawie badanym. Przedstawiono również wstępne wyniki badań zużycia frettingowego na modelu połaczenia obrotowego.
\end{abstract}

\section{Wprowadzenie}

Duże znaczenie dla usprawnienia ruchu kolejowego pomiędzy krajami mającymi różne szerokości torów ma wprowadzenie wagonów wyposażonych $\mathrm{w}$ zestawy kołowe o zmiennym rozstawie kół przejeżdżających bezpośrednio z toru normalnego na szeroki i odwrotnie przez torowe stanowisko przestawcze, wbudowane na styku obu torów.

W tym celu w latach 90 ubiegłego wieku w Centralnym Biurze Konstrukcyjnym PKP w Poznaniu pod kierunkiem R. Suwalskiego zaprojektowano i wykonano zestaw kołowy, który umożliwiałby bezobsługowy, samoczynny przejazd $\mathrm{z}$ toru o jednej szerokości na tor o innej szerokości, dokonywany na torowym stanowisku przestawczym [3]. Fragment przekroju zaprojektowanego zestawu przedstawiono na rys.1. Podstawowymi jego elementami sa;

- oś zestawu kołowego (1),

- dwa koła przemieszczające się po osi zestawu (2),

- mechanizm ryglujący (3)

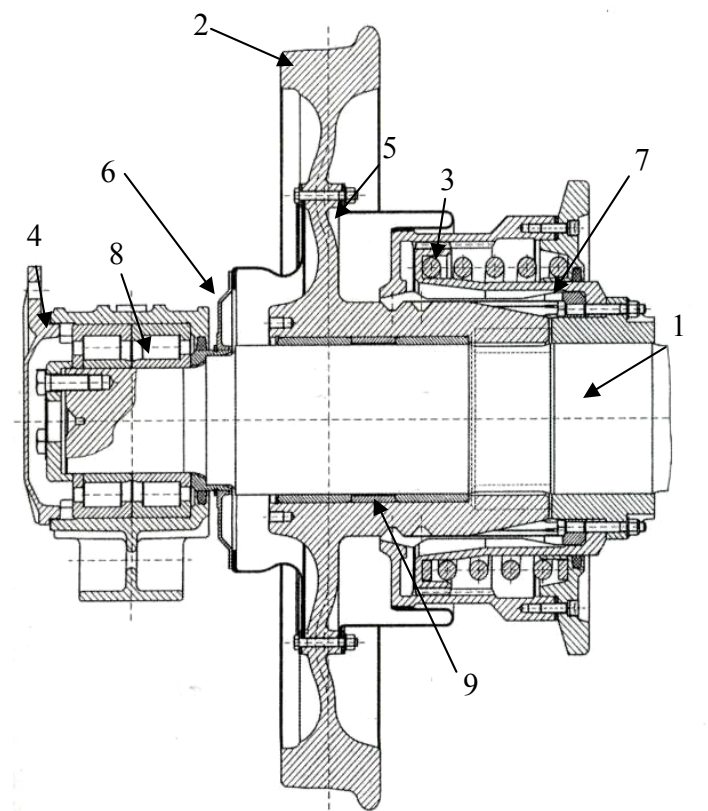

Rys.1. Przekrój zestawu kołowego z automatyczną zmianą rozstawu kół [3]
Istotnym elementem przedstawionej konstrukcji jest połączenie koła $\mathrm{z}$ osią. $\mathrm{W}$ przeciwieństwie do tradycyjnego zestawu kołowego, gdzie koła połączone są trwale $\mathrm{z}$ osią $\mathrm{w}$ wyniku wtłaczania jest ono połączeniem obrotowym. Rozwiązanie to umożliwia przemieszczanie poosiowe kół w trakcie zmiany ich rozstawu, przy następnym zablokowaniu koła względem osi w czasie jazdy. $\mathrm{W}$ prototypowym zestawie koło oraz oś wykonano z materiałów zgodnie $\mathrm{z}$ normami UIC. Koło ze stali R7E a oś A1N.

Wstępna eksploatacja zestawu pokazała, że już po niewielkim przebiegu (ok. 1,5 tys. $\mathrm{km}$ ) istnieją duże problemy w zmianie rozstawu kół [3]. Znacznie wzrastała siła niezbędna do przemieszczenia poosiowego kół, prowadząc nawet do uszkodzeń stanowiska przestawczego. Obserwacje powierzchni podpiaścia osi po demontażu zestawu kołowego pokazały występowanie m.in. uszkodzeń frettingowych w obszarze styku z piastą koła (rys.2) oraz znaczne procesy starzenia smaru powodujące zablokowanie koła na osi w trakcie zmiany jego rozstawu.

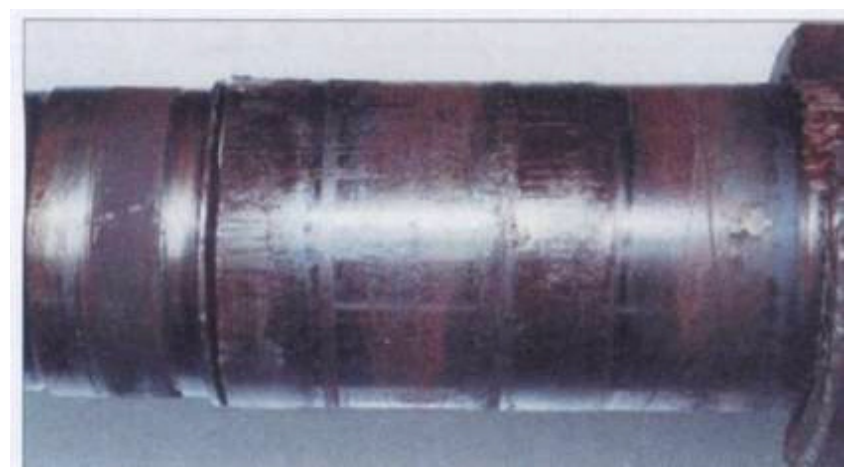

Rys.2. Uszkodzenia powierzchni podpiaścia osi zestawu kołowego z automatyczną zmianą rozstawu kół [3]

\section{Zużycie frettingowe w zestawach kołowych}

Fretting jest jednym $\mathrm{z}$ procesów niszczenia warstw wierzchnich elementów maszyn. O wystapieniu zużycia frettingowego decydują dwa czynniki: 
- styk dwóch powierzchni ciał,

- oscylacyjne przemieszczenia styczne powierzchni ciał o niewielkiej amplitudzie.

Fretting jest zjawiskiem o bardzo złożonym mechanizmie zużywania, w którym nakładają się lub następują po sobie; zużycie adhezyjne, zmęczenie powierzchniowe, odwarstwianie, utlenianie, ścieranie wierzchołkami nierówności i luźnymi produktami zużycia [2]. Obrazem zużycia frettingowego mogą być ślady korozji na powierzchni elementów, wzrost chropowatości powierzchni, mikropęknięcia w warstwie wierzchniej, wżery. Rozbieżności pomiędzy poszczególnymi badaczami wynikają głównie z przyjęcia jednego $\mathrm{z}$ tych procesów jako inicjującego rozwój zużycia frettingowego. To z kolei będzie zależeć od warunków badań zużycia frettingowego, czy dotyczyć on będzie styku konforemnego czy niekonforemnego lub np. połączeń wciskowych.

Warunki pracy analizowanego połączenia obrotowego koło - oś zestawu kołowego z automatyczną zmianą rozstawu kół można z pewnym przybliżeniem odnieść do połączenia wciskowego koło - oś tradycyjnego zestawu kołowego. Zasadnicza różnica jest jedynie w stanie naprężeń wstępnych wytworzonych w warstwie wierzchniej połączonych elementów. W połączeniu wciskowym w wyniku wtłoczenia koła na oś na całej powierzchni styku powstaje wstępny stan naprężeń ściskających i towarzyszący mu również stan deformacji w warstwie wierzchniej połączonych elementów. W przypadku natomiast połączenia obrotowego koło - oś zestawu kołowego z automatyczną zmianą rozstawu kół występuje jedynie styk niekonferemny i naprężenia są wynikiem siły normalnej pochodzącej od obciążenia zestawu.

Badania nad rozwojem zużycia frettingowego w połączeniu wciskowym koło - oś zestawu kołowego przedstawiono w pracy [1]. Badania prowadzono na próbkach modelujących rzeczywiste połączenie koło - oś. Celem badań było określenie mechanizmu rozwoju zużycia frettingowego w połączeniu wciskowym koło - oś oraz wpływ stanu powierzchni oraz parametrów montażu na intensywność zużycia. Najważniejsze wnioski wynikające $\mathrm{z}$ tych badań to:
- dominującą rolę w inicjacji zużycia frettingowego $\mathrm{w}$ połączeniu wciskowym spełnia zjawisko adhezji. Tworzenie się i rozrywanie sczepień adhezyjnych,

- intensywność zużycia zależy od sposobu wykonania połączenia wciskowego (wtłaczane lub skurczowe)

- $\quad$ w połączeniu wtłaczanym wzrost wartości wcisku lub zmniejszenie chropowatości łączonych powierzchni zwiększa intensywność zużycia.

Zużycie w połączeniu wciskowym ma charakterystyczny obraz w postaci pierścienia na całym obwodzie wałka o niewielkiej szerokości po obu stronach połączenia przy brzegu tulejki.

Istotny wpływ na rozwój zużycia frettingowego w połączeniu wciskowym ma stan powierzchni i warstwy wierzchniej połączonych elementów. Strefa ta w trakcie wykonywania połączenia ulega różnym deformacjom zależnym m.in. od sposobu wykonywania połączenia. Szczególnie ma to miejsce w przypadku połączenia wtłaczanego, gdzie w warstwie wierzchniej występuje ścinanie mikrowystępów i deformacje plastyczne (rys.4). W przypadku połączenia obrotowego nie występują tego typu zmiany. Charakter współpracy skojarzonych elementów będzie więc odmienny. $\mathrm{Z}$ tego powodu nie można mechanizmu rozwoju zużycia w połączeniu wciskowym przenieść wprost na połączenie obrotowe.

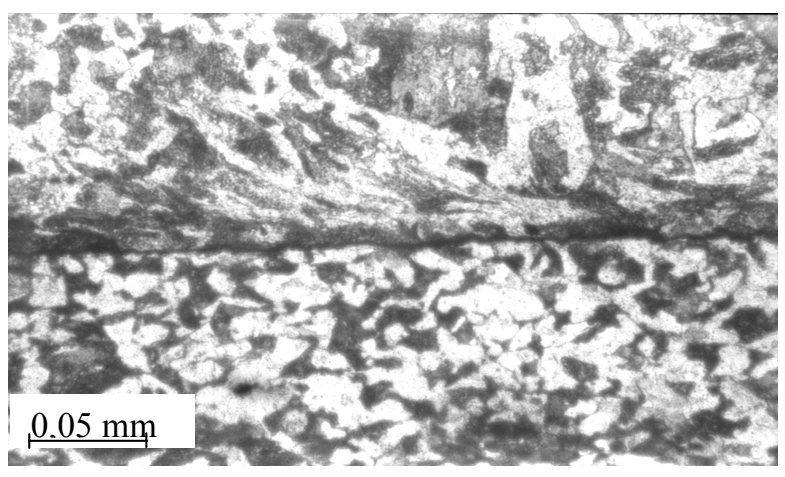

Rys.4. Obraz powierzchni styku wałka i tulejki, połączenie wtłaczane, pow. 320x

$\mathrm{F}$

b)

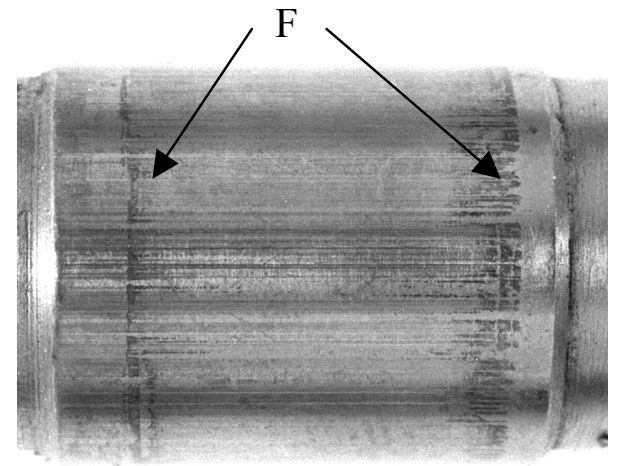

Rys.3. Fotografie powierzchni podpiaścia wałków z połączenia wciskowego po badaniach zużyciowych, pow. ok. 4x; [1] F - zużycie fretting, a) połączenie skurczowe, b) połączenie wtłaczane 


\section{Badania zużycia frettingowego $w$ połączeniu obrotowym}

Dla wyjaśnienia mechanizmu rozwoju zużycia frettingowego w połączeniu obrotowym oraz wpływu wybranych procesów technologicznych na jego intensywność przeprowadzono badania na próbkach modelujących rzeczywiste połączenie koło - oś w zestawie kołowym z automatyczną zmianą rozstawu kół. Wymiary próbki (wałek, tulejka) oraz materiał zostały tak dobrane aby zapewnić podobieństwo do prototypowego węzła rzeczywistego zestawu kołowego. Dobór innych materiałów miał na celu sprawdzenie czy taki zestaw ograniczy lub wyeliminuje zużycie frettingowe $\mathrm{w}$ połączeniu obrotowym. $\mathrm{Na}$ rys.5 przedstawiono zdjęcie próbki modelującej połączenie obrotowe koło-oś.

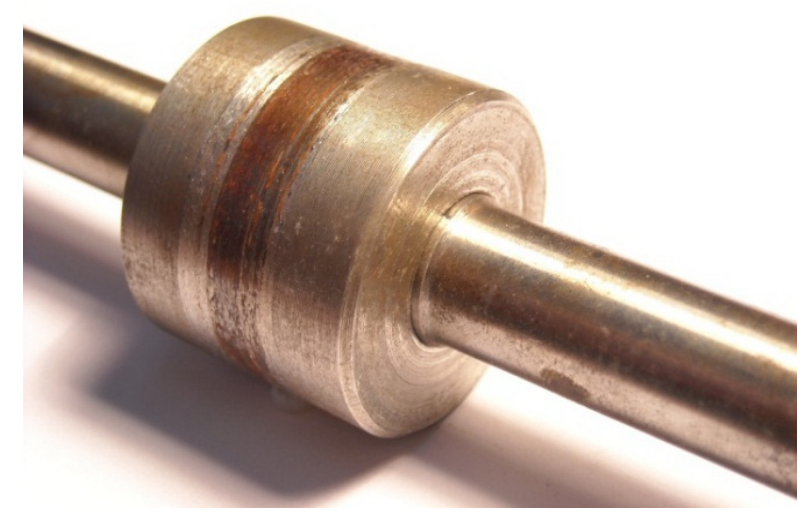

Rys.5. Próbka do badań modelowych połączenia obrotowego

Badania zużyciowe przeprowadzono na maszynie zmęczeniowej typu MUJ zapewniającej podobny charakter obciążenia $\mathrm{w}$ warunkach obrotowego zginania jak w rzeczywistym zestawie kołowym (rys.6).

Do badań wstępnych wytypowano próbki wykonane $\mathrm{z}$ różnych materiałów lub o różnych powłokach na powierzchni oraz $\mathrm{z}$ ewentualną warstwą smarną na powierzchni styku połączenia. Warianty wykonania modelu zestawiono w tabeli 1 .

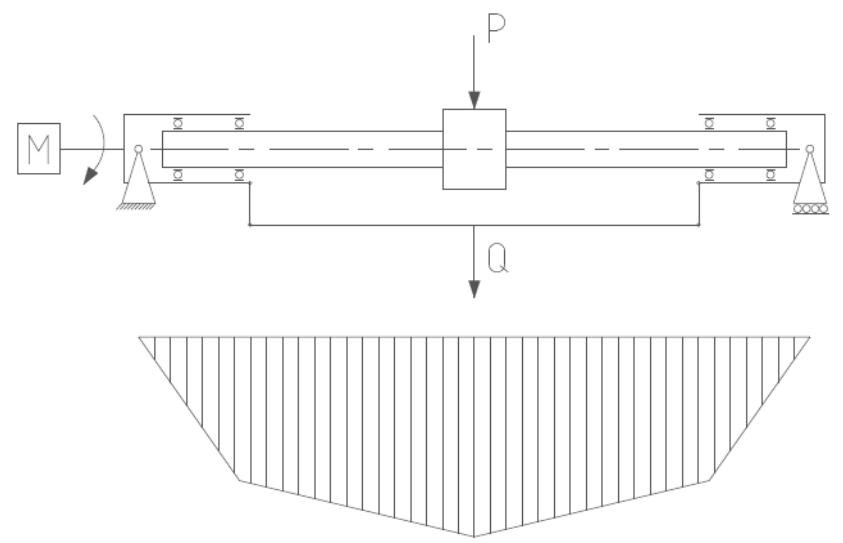

Rys. 6. Schemat obciążenia próbki i rozkład momentu gnącego
Tabela 1

Warianty wykonania modelu polączenia obrotowego wałek tulejka wytypowanych do badań zużyciowych.

\begin{tabular}{|c|c|c|c|}
\hline Lp. & $\begin{array}{c}\text { Powierzchnia } \\
\text { podpiaścia } \\
\text { wałka }\end{array}$ & $\begin{array}{c}\text { Materiał } \\
\text { tulei }\end{array}$ & $\begin{array}{c}\text { Rodzaj } \\
\text { smaru }\end{array}$ \\
\hline 1 & stal & stal & - \\
\hline 2 & molibden & stal & - \\
\hline 3 & stal & 1fx (black) & - \\
\hline 4 & stal & stal & Glacier \\
\hline
\end{tabular}

Na kolejnych rysunkach (rys.7-10) przedstawiono obraz powierzchni podpiaść wałków po badaniach zmęczeniowych.

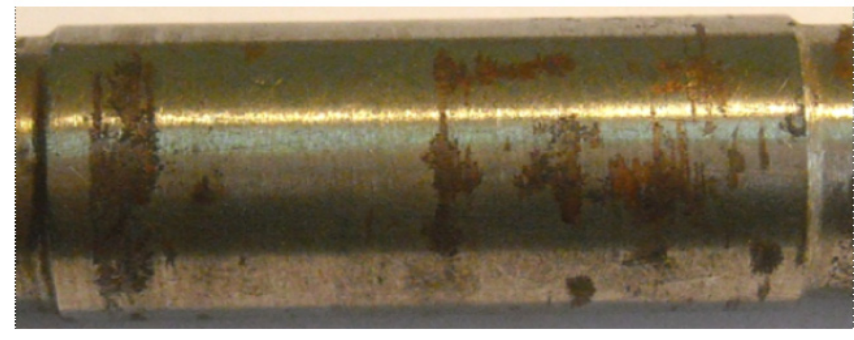

Rys.7. Obraz powierzchni podpiaścia wałeczka stalowego w skojarzeniu ze stalową tulejką - wyraźne ślady zużycia frettingowego

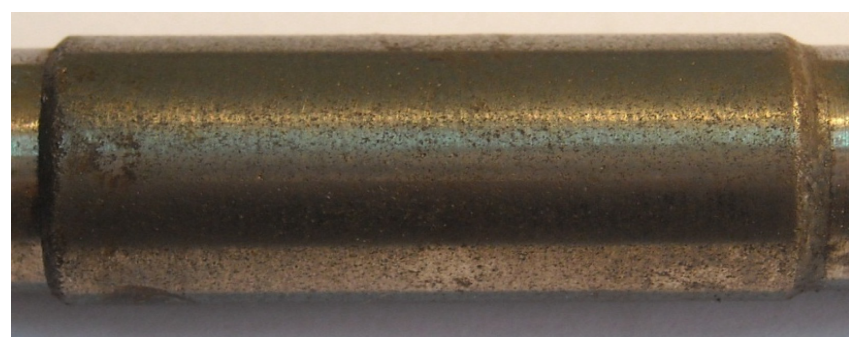

Rys.8. Obraz powierzchni podpiaścia wałeczka molibdenowanego w skojarzeniu ze stalową tulejką - brak śladów zużycia frettingowego

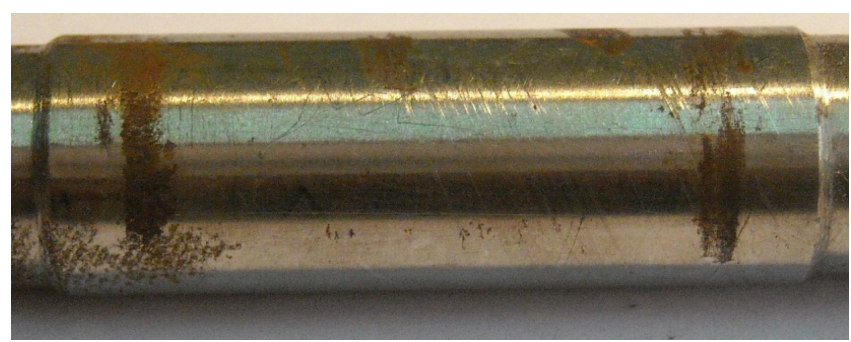

Rys.9. Obraz powierzchni podpiaścia wałeczka stalowego w skojarzeniu z tulejką z tworzywa (lfx) - wyraźne ślady zużycia frettingowego

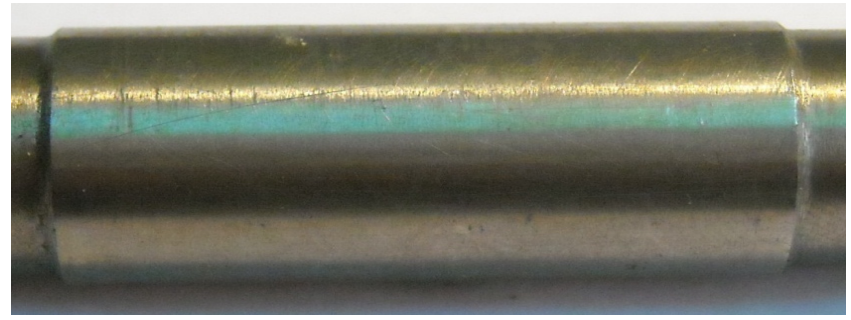

Rys.10. Obraz powierzchni podpiaścia wałeczka stalowego w skojarzeniu ze stalową tulejką oraz smarem Glacier na powierzchni styku- brak śladów zużycia frettingowego 


\section{Zakończenie}

Przytoczone wyniki badań potwierdziły występowanie zużycia frettingowego $\mathrm{w}$ połączeniu obrotowym. Ponadto wykazano, że badania można prowadzić na próbkach modelujących rzeczywiste połączenie obrotowe koło - oś. Obraz zużycia frettingowego występujący na próbkach wykonanych ze stali (podobnie jak w rzeczywistym prototypowym zestawie) wskazuje na podobny charakter uszkodzeń jak w przypadku połączeń wciskowych. Ponadto potwierdza wniosek $\mathrm{z}$ badań $\mathrm{w}$ połączeniach wciskowych, że materiały o zbliżonym składzie i własnościach mechanicznych są bardziej podatne na rozwój zużycia frettingowego. $\mathrm{Z}$ kolei brak uszkodzeń na powierzchni wałka molibdenowanego potwierdza wniosek z pracy [1], że duży gradient twardości skojarzonych powierzchni ogranicza rozwój zużycia frettingowego m.in. w wyniku ograniczenia możliwości do tworzenia sczepień adhezyjnych skojarzonych powierzchni. Podobne działanie ma miejsce $\mathrm{w}$ przypadku powierzchni pokrytych smarem Glacier. Warstwa smaru nie dopuszcza do bezpośredniego kontaktu skojarzonych powierzchni ograniczając tym również możliwość tworzenia sczepień adhezyjnych.
Przytoczone wnioski z dotychczas przeprowadzonych badań wskazują, że mechanizm rozwoju zużycia frettingowego $\mathrm{w}$ połączeniu obrotowym będzie podobny do zużycia w połączeniu wciskowym. Procesem inicjującym rozwój zużycia frettingowego również będą zjawiska adhezji. Natomiast zakres jego występowania, wpływ czynników technologicznych i konstrukcyjnych na intensywność zużycia wymaga dalszych badań.

\section{Lit e r a tura}

[1] Guzowski S.: Analiza zużcia frettingowego w potaczeniach wciskowych na przykladzie osi zestawów kotowych pojazdów szynowych. Monografia 284, wyd. Politechniki Krakowskiej, Kraków 2003.

[2] Neyman A.: Fretting w elementach maszyn. Wyd. Politechniki Gdańskiej, Gdańsk 2003

[3] Suwalski R.: System samoczynnej zmiany rozstawu kót pojazdów szynowych. Monografia 154, wyd. AGH Kraków, 2006.

[4] Waterhouse R.B.: Fretting fatigue. Applied Science Publishers Ltd., London, 1981. 